\title{
Implementation of Standards Occupational Safety and Health at the Public Health Center in Banda Aceh
}

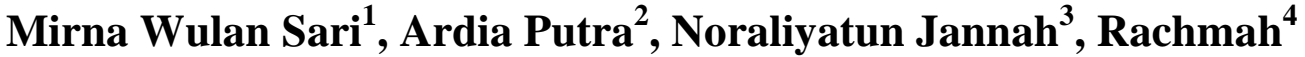 \\ ${ }^{1}$ Graduate Student of School of Nursing, Faculty of Nursing, Universitas Syiah Kuala, Banda Aceh, Indonesia \\ ${ }^{2}$ Senior Lecturer of Fundamental \& Management of Nursing Department, Faculty of Nursing, Universitas Syiah \\ Kuala, Banda Aceh, Indonesia \\ ${ }^{3,4}$ Lecture of Fundamental \& Management of Nursing Department, Faculty of Nursing, Universitas Syiah Kuala, \\ Banda Aceh, Indonesia \\ Corresponding Author: Ardia Putra
}

\begin{abstract}
Background: Health services provided by health workers, especially nurses, can put them in a risky situation that can endanger patients and causing work accidents. A work accident is an incident that does not happen by chance but has a cause. Therefore, work accidents must be observed and the reasons found to prevent similar incidents and not happen again. The study aims to determine occupational safety and health standards at the Public Health Center in Banda Aceh city.

Methodology: This quantitative study is applied with a cross-sectional study design approach. This research was conducted in 6 Public Health Centers in Banda Aceh City. The population of this study amounted to 44 people, and there were 39 nurses taken as samples. Samples were collected using the total sampling technique with the inclusion criteria. This research tested for validity and obtained results with $r$ values above the $r$ table value $(0,482)$ and a reliability test with Cronbach's Alpha value of 0.81. Data collection by distributing questionnaires directly to respondents. This study uses univariate analysis.
\end{abstract}

Results: This study indicated that the application of occupational safety and health standards at the Public Health Center in Banda Aceh city was in a suitable category, with as many as 36 respondents $(92,3 \%)$.

Conclusion: From the results above, it is hoped that the head of the Public Health Center will continue to support staff in improving occupational safety and health in the work environment.

Keywords: Occupational health and safety, work accidents, public health center

\section{INTRODUCTION}

Public Health Center/Puskesmas is one of the first-level service places that have a crucial role and function in efforts to improve public health as a provider of public health services that are part of the community's health resources (1).

Regulation of the Minister of Health of the Republic of Indonesia Number 52 of 2018 concerning Occupational Safety and Health in Health Service Facilities (2), Article 3 paragraph 1 states that every health service facility is obliged to organize an occupational safety and health program or abbreviated as $\mathrm{K} 3$ in health service facilities. The types of health service facilities according to the Government Regulation of the Republic of Indonesia Number 47 of 2016 concerning Health Service Facilities (3), one of which is a Public Health Center (PHC).

Nurses are considered a part of health care providers' work so that patients are in a safe environment and face various risks to their safety and health. Occupational Safety and Health (OSHA) describes five nurse safety risks that nurses must face in the environment. Its work includes 
biological, chemical, physical, environmenttal ergonomics, and psychosocial hazards (4).

A study conducted by Kusman in Laranova et al. (5) in West Java province, it was found that work-related incidents such as needle sticks (32.8\%), knife cuts (3.3\%), injuries (24.5\%), and splashes of blood and other body fluids $(39,4 \%)$. In another study conducted by Surbakti et al. (2018) through brief interviews with seven health workers at Puskesmas X Semarang City, it was found that $71,43 \%$ had been pierced by a needle, $57.14 \%$ had slipped while working, and $71.43 \%$ had stumbled or been hit while working. A work accident is an event that does not happen by chance but has a cause. Therefore, accidents must be investigated and the causes found to prevent similar incidents and do not happen again (Suma'mur, 2013; Putri et al., 2018).

During a pandemic such as Covid19, currently, health care facilities have a high risk of occupational accidents and occupational diseases. Vigilance regarding the application of OSHA during a pandemic is increasing compared to everyday situations. In addition, the availability of PPE and other supporting equipment must be a significant concern, for now, considering that health workers are the central element in handling Covid-19 (7). Therefore, it is essential to apply PPE in preventing transmission of infection when carrying out actions taken by health workers, especially nurses (8).

Based on the description and explanation above, the researcher is interested in researching the implementation of OSHA standards at the PHC in the working area of Banda Aceh.

\section{MATERIALS \& METHODS}

A descriptive study was applied in this research, with the type of research is quantitative - a cross-sectional study approach. The study was conducted in all public health centers in Banda Aceh, totalling six health centers. The total population of this study amounted to 44 people. In the sampling technique using the total sampling method, 39 respondents met the inclusion criteria, while the inclusion criteria were: willing to be a respondent in research without coercion from any party, not in a sick condition, and not in the process of taking leave. Five respondents were not involved in this study because they were undergoing self-isolation due to exposure to the Covid-19 virus.

This study uses a significance level of $5 \%$. The questionnaire consists of 13 statement items. This research has been tested for validity, and the results obtained with the calculated $r$-value above the $r$ table value $(0,482)$ and reliability test with Cronbach's Alpha value 0,81. The review board conducted the ethical consideration from the Faculty of Nursing, Universitas Syiah Kuala. Its review considers six aspects: autonomy, beneficence, justice, nonmaleficence, veracity, and confidentiality. Data collection was carried out for 13 days from August 19 to August 31 , 2021, by distributing questionnaires developed by the researcher in the form of a Likert scale with three answer choices, namely "Yes," "Uncertain," and "No."

\section{RESULTS}

Table 1. Respondents Demographic Data $(\mathbf{N}=39)$

\begin{tabular}{|l|l|l|l|}
\hline No & Category & Frequency & $(\%)$ \\
\hline 1. & Gender & 4 & \\
& Male & 35 & 10.3 \\
& Female & & 89.7 \\
\hline 2. & Age & 7 & \\
& 26-35 years & 23 & 17.9 \\
& 36-45 years & 7 & 59 \\
& 46-55 years & 2 & 17.9 \\
& 56-65 years & & 5.1 \\
\hline 3. & Education & 34 & \\
& D3 & 2 & 87.2 \\
& S1 & 3 & 5.1 \\
& Ners & & 7.7 \\
\hline 4. & Length of Work & 4 & \\
& <6 years & 6 & 10,3 \\
& 6-10 years & 29 & 15,4 \\
& $>10$ years & 39 & 74,4 \\
\hline & Total & & 100 \\
\hline
\end{tabular}

Based on Table 1 above, it is known that the respondents in this study were primarily female as many as 35 people $(89,7)$, late adult age group (36-45 years) as many as 23 people (59\%), most of the respondents have a D3 education level as 
many as 34 people $(87.2 \%)$. They have worked for more than ten years as many as 29 people $(74,4)$.

Table 2. Implementation of Occupational Health and Safety Standards in PHC $(\mathbf{N}=39)$

\begin{tabular}{|l|l|l|l|}
\hline No & Category & Frequency & $(\mathbf{\%})$ \\
\hline 1. & Good & 36 & 92,3 \\
2. & Poor & 3 & 7,7 \\
\hline & Total & 39 & 100 \\
\hline
\end{tabular}

Based on Table 2, it is known that some respondents have a good level of perception of occupational safety and health standards, as many as 36 respondents $(92.3 \%)$.

Table 3. Crosstab Characteristics of Respondents Based on Age

\begin{tabular}{|l|l|l|l|l|l|}
\hline No & \multirow{2}{*}{ Age } & Good & Poor & \\
\cline { 3 - 6 } & & Frequency & $(\boldsymbol{\%})$ & Frequency & $(\boldsymbol{\%})$ \\
\hline 1. & $26-35$ years & 7 & 19.4 & 0 & 0 \\
\hline 2. & $36-45$ years & 20 & 55.5 & 3 & 100 \\
\hline 3. & $46-55$ years & 7 & 19.4 & 0 & 0 \\
\hline 4. & $56-65$ years & 2 & 5.5 & 0 & 0 \\
\hline \multicolumn{2}{|l}{ TOTAL } & 36 & 100 & 3 & 100 \\
\hline
\end{tabular}

Table 3 shows that the highest level of perception is in the late adult phase, with 20 respondents $(55.5 \%)$ having a good perception of the application.

\section{DISCUSSION}

The results showed that nurses' perceptions of applying occupational safety and health standards within the Puskesmas were in a good category, with as many as 36 respondents $(92.3 \%)$. It can be concluded that some respondents in this study already have a good perception of occupational safety and health.

The results of this study are supported and in line with the research conducted by Nada et al. (9), which shows that Puskesmas $\mathrm{X}$, located in the Pekalongan district, already has a K3 commitment. As evidence is the existence of the OSHA Decree for the head of the Puskesmas and its implementing team; the existence of competent resources supported by training and allocation of funds; the availability of B3 waste management; and the existence of SOPs and PPE in acting.

Another study conducted by Enisah and Susanto (10) showed that the Cijagra Lama Health Center in Bandung had 80\% fulfilled the requirements following the Regulation from the Minister of Health Number 52 of 2018 concerning OSHA. However, it is still necessary to improve and improve the performance of $\mathrm{K} 3$ on the elements of facilities and infrastructure in the transfer of goods and patients, periodic health checks, immunization of health workers at risk, maintenance of medical equipment, and the need for training.

This study shows that the majority of respondents are in the late adult phase (3645 years) as many as 23 respondents (59\%), the majority of respondents (20/36 respondent $=55.5 \%$ ) who are in this phase have a good perception of the implementation of $\mathrm{K} 3$ at the Puskesmas in the working area of Banda Aceh City. According to Tanto (2012) and Mahendra and Woyanti (2014), as cited in Aprilyanti (11), one of the factors that affect the level of productivity is age. Those who are still in their productive period usually have a higher productivity level than older people who have physical limitations that become weak and limited.

\section{CONCLUSION}

Based on the results of research conducted on 39 respondents, it was found that the application of occupational safety and health standards at the Public Health Center in Banda Aceh City was in a good category, as many as 36 respondents (92.3\%). However, several things must be improved so that the OSHA program can run optimally. Such as involving everyone (healthcare and non-healthcare providers) in the preparation of the OSHA program, the existence of socialization regarding OSHA, the commitment from top-level management, the availability of adequate facilities and infrastructure, and the existence of training on OSHA. It is hoped that the head of the Puskesmas will involve all health workers in making the OSHA program. It will be written down in a lettered policy and signed by the leader and disseminated to all health workers in their work environment. Thus, for further 
researchers it's recommended to conduct on the factors that influence the application of occupational safety and health standards.

\section{Acknowledgement: None}

\section{Conflict of Interest: None}

\section{Source of Funding: None}

\section{REFERENCES}

1. Wijayanti R, Probandari A, Aini MR, Salim AW, Amalia HU, Adji BP, et al. Identifikasi Bahaya, Penilaian Risiko dan Penentuan Kontrol di Puskesmas Gambirsari Surakarta [Hazard Identification, Risk Assessment and Control Determination at Gambirsari Public Health Center Surakarta]. Indones J Med Sci. 2017;4(2):150-6.

2. Kementerian Kesehatan RI. Peraturan Menteri Kesehatan Republik Indonesia Nomor 52 Tahun 2018 Tentang Keselamatan dan Kesehatan Kerja di Fasilitas Pelayanan Kesehatan [Regulation of the Minister of Health of the Republic of Indonesia Number 52 on 2018 concerning Occupational Safety. 52 Jakarta, Indonesia; 2018 p. 1-65.

3. Peraturan Pemerintah RI. Peraturan Pemerintah Republik Indonesia Nomor 47 Tahun 2016 Tentang Fasilitas Pelayanan Kesehatan [Government Regulation of the Republic of Indonesia Number 47 on 2016 concerning Health Service Facilities]. 2016 p. $1-15$.

4. Tweedy JT. Healthcare Safety for Nursing Personnel: An Organizational Guide to Achieving Results. New York: CRC Press; 2015.

5. Laranova A, Afriandi I, Pratiwi YS. Persepsi Tenaga Kesehatan terhadap Penggunaan Alat Pelindung Diri dan Kejadian Kecelakaan Akibat Kerja di Salah Satu Rumah Sakit di Kota Bandung [Perceptions of Health Workers on the Use of Personal Protective Equipment and Occupational Accidents at a Hos. J Sist Kesehat. 2018;3(4):189-97.

6. Putri S, Santoso, Rahayu EP. Pelaksanaan keselamatan dan kesehatan kerja terhadap kejadian kecelakaan kerja perawat rumah sakit [Implementation of occupational safety and health on the incidence of occupational accidents in hospital nurses]. J Endur. 2018;3(2):271-7.

7. Sholikin MN, Herawati. Aspek Hukum Keselamatan dan Kesehatan Kerja (K3) Bagi Tenaga Medis dan Kesehatan di Masa Pandemi [Legal Aspects of Occupational Safety and Health (K3) for Medical and Health Workers during a Pandemic]. Maj Huk Nas. 2020;50(2):163-82.

8. Nirmalarumsari C. Hubungan Tingkat Pengetahuan, Sikap, dan Kedisiplinan Perawat dengan Penggunaan APD di Masa Pandemi COVID-19 di Puskesmas Wara Selatan Kota Palopo [Relationship Level of Knowledge, Attitude, and Discipline of Nurses with the Use of PPE during the COVID-19. J Kesehat Luwu Raya. 2021;8(1):21-30.

9. Nada FQ, Denny HM, Setyaningsih Y. Implementasi Keselamatan dan Kesehatan Kerja di Puskesmas: Studi Kasus di Kabupaten Pekalongan [Implementation of Occupational Safety and Health at the Puskesmas: A Case Study in Pekalongan Regency]. J Manaj Kesehat Indones. 2020;8:98-104.

10. Enisah E, Susanto A. Evaluation of Occupational Health and Safety Management System (SMK3) Health Service Facilities at Puskesmas Cijagra Lama. J Aisyah J Ilmu Kesehat. 2020;5(2): $143-51$.

11. Aprilyanti S. Pengaruh Usia dan Masa Kerja Terhadap Produktivitas Kerja (Studi Kasus : PT. OASIS Water International Cabang Palembang) [Effect of Age and Working Period on Work Productivity (Case Study: PT. OASIS Water International Palembang Branch)]. J Sist dan Manaj Ind. 2017;1(2): 68-72.

How to cite this article: Sari MW, Putra A, Jannah $\mathrm{N}$ et.al. Implementation of standards occupational safety and health at the public health center in Banda Aceh. Gal Int J Health Sci Res. 2021; 6(4): 6-9. DOI: https://doi.org /10.52403/gijhsr.20211002 